\title{
JOHN BEAUCHAMP JONES: A SOUTHERN VIEW OF THE ABOLITIONISTS
}

\author{
BY FREDERICK R. LAPIDES \\ Dr. Lapides is Associate Professor of English at the \\ University of Bridgeport
}

$\mathbf{J}$

OHN Beauchamp Jones, born in Baltimore in $18 \mathrm{ro}$, wrote a number of novels that are today seldom read. He served as a clerk, supporting the cause of the South during the Civil War, and died in 1 866, the year in which his Rebel War Clerk's Diary was published. His novels are without literary distinction, but one work remains of interest because of its unusual treatment of a contemporary event. This novel, a dream vision of a war between the states, was titled Border $W$ ar, and was published in 1859 ; it was republished, unaltered except for its title, in I86I as Secession, Coercion, and Civil War: the Story of ${ }_{1} 86 r{ }^{1}{ }^{1}$ According to the publisher's blurb, "Everybody will read it, and the effect it will have will be of the most salutary kind, and, by showing the ill effects of Coercion and Disunion, will draw the bands of Fraternity yet closer midst the various sections of our great Republic."

But when the Civil War began, Jones, highly critical of Davis' performance as president of the Confederacy, earned the hatred of his fellow Southerners. He moved North after the war, and died in Burlington, New Jersey, while seeing his diary through the press.

Jones' novel is of interest as an indication of a Southern attitude toward the sectional strife that was to culminate in the Civil War. The Union, Jones believed, must be preserved. Yet as a Southerner, Jones believed that there were just grievances in the South against Northern politicians and abolitionists who sought to impose their beliefs upon the South.

1 John Beauchamp Jones, Secession, Coercion, and Civil War: the Story of ${ }_{I} 86 \mathrm{I}$ (Philadelphia; T. B. Peterson and Brothers, 186I). I wish to thank Mr. Donald Sinclair, Curator of Rutgers Library Special Collections, for bringing this novel to my attention. 
In Jones' novel, the North is the aggressor, the North calls for secession, and the North is finally defeated by the federal forces, combined with the Southern forces. Jones' dream vision, then, is a wish-fulfillment, a desire to convince the North that its fanatics will cause the Union to crumble. In order to understand Jones' attitudes toward the abolitionists, a simplification of a fairly complicated novel is necessary. The outline that follows focuses mainly upon the political aspects of Jones' novel.

A substantial number of congressmen from both the North and the South abandon their seats in Washington, intent upon dissolving the Union because of the slavery issue. Individual states begin to convene meetings to decide upon a future course of action; civil war and anarchy threaten. But President Randolph, a Southerner, resolves to keep the Union together-with or without Congress. He plans to use the militia at his disposal to intervene whenever necessary in order to maintain a balance of power between the North and the South until such time as the contending forces realize the wisdom of maintaing the Union.

In the South, General Crook, a self-proclaimed fireeater, tries to capture the President in order to destroy the Union, but his efforts fail. The Southern states decide to place General Blount at the head of all the Southern forces, despite Crook's popularity. Blount is a more reasonable man than Crook, but he too is in favor of dissolving the Union. A plot is discovered in the South "for the enfranchisement of the slaves and the massacre of the white population." Many whites and still more of "the deluded slaves paid the penalty of following the evil counsels of their worst foes in the disguise of friends." However, when this conspiracy was made fully known throughout the Southern states, sentiment for a complete break with the Union grew stronger. A convention of Southern states met to vote upon dissolving the Union, but a decision was postponed until a time when the states might be more united among themselves. Jones' plotting of the novel thus makes the North responsible for the beginning of hostilities.

The Northern states select General Hudson as their supreme commander. $\mathrm{He}$ is assassinated, however, seemingly by agents of General Ruffleton, the Northern general who is the villain in the novel. 
Through various manipulations, Ruffleton gets the North to withdraw from the Union and has himself declared "Lord Protector" of the North, assuming full dictatorial powers.

The North invades Southern territory, but Crook, with the blessings and support of President Randolph, beats back Ruffleton's forces. Crook is incensed and invades the North. He demands tribute from New York as his price for not attacking it. This tribute obtained, he withdraws to Southern territory, again because of the intervention of President Randolph.

While this domestic problem becomes increasingly complicated, foreign nations have been keeping a careful watch over events. The British throw in their lot with Ruffleton in order to help destroy the only important example of a republican form of government. In return for money and ships, Great Britain is to receive trade concessions and some territory in the Southern hemisphere. Late in the novel, the French and Russian governments pledge their aid to the federal forces-those troops and citizens supporting President Randolph-but their help is never needed. President Randolph welcomes Great Britain's support of the North; he feels this will help bring sympathy from both the North and the South toward the federal government, and that the British will be a reminder to Americans of the American revolution.

Crook has scored two victories over Ruffleton, and the Northern general, determined to wipe out his Southern opponent and the federal forces, stages a massive invasion of the South. The Southern cause and the federal cause now become one. From this point in the novel until the conclusion, General Blount (Southern commander), General Crook, and President Randolph fight the common enemy; their forces are referred to as the Federal troops.

President Randolph wisely suggests an orderly withdrawal deep into the South. Ruffleton in hot pursuit overextends himself; his forces are destroyed by disease and hunger. President Randolph attempts as much as possible to avoid killing fellow Americans. Meanwhile, in the North, rebellion against Ruffleton's tyrannical rule breaks out. Ruffleton unwisely tries to win support in the South that he is invading by his announcement of the "Richmond Proc- 
lamation," a document that recognizes slavery for both the South and the North.

This bold step by Ruffleton fails, however, for the British withdraw their support of the North because they are unable at this time in their history to support slavery. Though Ruffleton occupies Washington and his troops have burned down Mt. Vernon, the tide clearly begins to turn against him. In the South the Richmond Proclamation also creates problems for Ruffeton. The Southern General Fell decides that Randolph has not been faithful to his heritage and has not taken advantage of Ruffleton's weakened forces; Fell believes that Randolph should attempt a military victory, a massive onslaught against the Northern invaders. General Fell decides to throw in his forces with Ruffleton, since Ruffleton has gone on record as being in favor of slavery for both the North and the South. In addition, Fell has hopes that some day he may become an important political figure.

But General Fell's forces consist primarily of Negro slaves. And when President Randolph, through an intermediary, convinces the slaves that they would be simply exchanging one set of masters for another, they lay down their arms and refuse to fight against the Southern and Federal forces. The slaves are convinced that the kindness they receive from Southern masters would not be forthcoming from harsh Yankee masters.

Ruffleton's last hope has vanished. Defeated, he flees on a ship bound for Europe. The country, under Randolph, is reunited.

In order to understand Jones' attitude toward the Northern abolitionists, the reader must distinguish between and among speakers. General Crook is fanatic in his hatred of Northern fanaticism, but a number of his remarks seem to win approval from President Randolph, who seems to represent the author's point of view. Crook's attitude, early in the novel, is that "For many years I have longed for an opportunity such as this. The South will throw off her degrading vassalage. We shall have great cities and fleets, and factories of our own." But even before the military men can make their positions and strengths felt, guerrilla warfare and mob action break out. Native Southerners who are living or visiting in the North are brutally punished on the suspicion that they may have pro-slavery sympathies. These mob actions, says Jones, were used by "profligate, 
revengeful, and grasping wretches" to get even with "the rich, the exalted, and purest members of society."

So, too, in the South. The difference, according to Jones, is that in the South there are no large mobs because "no large cities existed to harbor any formidable number of the degraded class of population, ever infesting dense communities, whose demonic delight consists in the misfortunes of others."

General Ruffleton is never identified as an abolitionist. In fact, one of his followers asserts that the general is moving toward Delaware not to advance anti-slavery views but "to wipe out all the niggers as we go!" More often than not, Northerners are either fanatics (i.e. abolitionists) or hypocrites, though one Northern senator states that he is not a fanatic, "though opposed to slavery."

Among the chief leaders of the abolition movement is a Rev. $\mathrm{Mr}$ Fire, who takes advantage of the confusion sweeping the border states in order to get vengeance upon his foes. In Philadelphia, he personally leads a mob in the construction of cages that will imprison his anti-abolition foes. He places the prestigious Senator Langdon in one of these cages to make an example for the "benefit of some other public men who have been too fond of Southern associates." In another cage, the mob places the publisher of a Democratic journal which "had always been very bitter in its strictures against the Abolitionists." Other cages contain editors and politicians; an editor is imprisoned, his hands tied behind him, while a young Negro in a parody of a slave auction offers him for sale: "He is a great worker, and can see without specks, sir, and dat's what his age is." There are no buyers.

The rioting initiated by Rev. Mr. Fire quickly turns against him. While he is busy tormenting his enemies a roving band sacks his church, stealing \$IOO,000 that had been placed with him for safe keeping. The abolitionists, says Jones, were astonished, "for the wind they had sown converted into a whirlwind and was directed against them." Hundreds of free Negroes were killed by the mob; "the survivors of that miserable race" fled into the forests of New Jersey. Jones explains that this turn in events was caused because so many free-soil recruits had left the city to join Gen. Ruffleton. When a well-known Northern orator, considered a friend of the 
Negro, pleads for the restoration of order, he is attacked by the Negroes, who believe that he has sold out. Thus, says Jones, the orator was forced to endure "the bitter penalty of their native inferiority and ingratitude." The Negroes, in turn, were attacked and slaughtered by the mob.

As the chaos continues to grow, the abolitionists suffer the brunt of the mob's fury. The cages that they had constructed are now used to imprison them. In one cage is a middle-aged Quaker. Within the same cage is Frederick Douglass. ${ }^{2}$ Douglass is seated in a barber's chair, and the Quaker is forced to read "W - - 's" poems to him ("an unmixed African!"). But the Quaker does not need to be goaded to his task. Jones observes that he seems to enjoy reading the poetry, "with the hope, that the hearts of his enemies would be touched." Douglass is embarrassed, and his request to exchange places with the Quaker is granted by his persecutors. This exchange, an onlooker observes, demonstrates "the relative positions of the two races."

Another cage also contains a Quaker, this one tarred and feathered for his complicity in "depriving a Southern citizen of his slaves." In yet another cage is "a colored specimen" and three white men, his "constant admirers." The abolitionists are required to kiss the Negro every third minute. This, says Jones, was a "great torture to them all," the Negro and the white men.

Former judges, anti-slavery biographers, editors and publishers are confined in a "literary cage"; their only punishment was public humiliation. The last cage referred to by Jones is by far the most raucous. Of mammoth dimensions, from which proceed a "medley of discordant sounds," this cage contains "a dozen distinguished women, Abby K., Lucy S., L.M., Mrs. S., etc.” Jones suggests that this treatment is inhuman but his remarks concerning the fanaticism of the abolitionists leaves the reader with the impression that Jones believes that the abolitionists have brought about their own punishment.

The turmoil reverberates throughout the country. New York is

${ }^{2}$ Frederick Douglass, the Negro abolitionist, journalist, orator (I817?-1895). Douglass is today remembered for his Narrative of the Life of Frederick Douglass, an American Slave (1845). 
one-fourth in ashes. Boston has a "Reign of Terror never surpassed in Paris." In Boston, Unitarians fought the Catholics until the city "fell completely into the hands of the foreign population." Abolition advocates and leaders such as "the Rev. T---e P---r, W---ll P---S, Wm. Lloyd G--n, ${ }^{3}$ Senators $S_{---r}$ and $W--N$, and the chivalrous B---e, with sundry masculine women, and lesser clerical abolition lecturers, including Mr. K---11---h," were placed aboard a ship and sent to Liberia.

This punishment of the abolitionists is the result of Northern mob actions. But when the North invades the South, and many Northern prisoners are taken by General Crook, he, too, indicates his intense dislike of the abolitionists. Thus, abolition members of Congress and the "many political parsons, and the editors and reporters" are rounded up and shipped to Liberia, an imitation of what the mob at Boston has done. Crook discovers that W---ll $\mathrm{P}---\mathrm{S}$ has escaped the Boston mob and had not been sent abroad; this time he is securely placed aboard the Liberia-bound ship. The Rev. Mr. Blood, Rev. Mr. Carp, Rev. Mr. F---e, Rev. Mr. Cleaver, and Rev. Mr. Aaron are also among Crook's prisoners. All are banished "to the distant coast of Africa," says Crook, so that they "might be satiated with the negro without annoying decent white people."

Though Crook has repelled Ruffleton in this first invasion of the South, he is enough of a firebrand to want vengeance. He invades the North. President Randolph is alarmed by this attack, and suggests to Gen. Hudson (supreme Southern commander) that Crook be allowed to penetrate only so far as the Hudson River. If Crook is defeated, Randolph reasons, then both the North and the South will see the futility of civil war. Randolph states that he has "Crook's pledge that he will not wreak his vengeance on any but the Abolitionists, and it will do no harm to demonstrate to these fanatics what they have wrought. ... A rebuke to these meddlesome fanatics will afford as much gratification to the conservative and patriotic citizens of the free States as any others." This, then, is the view of the calm,

\footnotetext{
${ }^{3}$ William Lloyd Garrison, an important figure in the anti-slavery movement (1 $805^{-}$ I 879). Garrison founded the Liberator magazine, which represented the extremist wing of the abolition movement. I have not speculated upon the other names that Jones hints at. Curiously, Jones is reticent at naming fully those abolitionists he is mocking but shows no similar reluctance in using the full name of Frederick Douglass.
} 
objective president, who claims to be impartial, and whose opinions probably represent those of the novelist.

General Crook with some IOO,OOO men marches through New Jersey. He finds that "in most localities in the country, where the anti-slavery party had triumphed at the polls, a vast proportion of the defeated Democrats seemed strongly inclined to espouse the cause of the Southern people." The general sends out troops in search parties to capture all the fugitive slaves; they inflict "fearful retribution on all who had participated in stealing or harboring that species of property." Quakers were compelled to supply food and shelter for the Southern troops, and "peculiarly obnoxious" Quakers have their goods confiscated, their homes burned to the ground.

General Crook reaches the Hudson River and prepares to attack the city of New York; he demands a tribute as his price for not assaulting the city. The tribute is to be four million dollars, a reasonable price, according to Crook: "It is less than one-tenth the value of the slaves your negro-stealers have deprived us of. It is a moderate quota for New York." According to the General's breakdown of this figure, two million is to pay for stolen slaves, and "two millions for harboring the political parsons and Abolition editors who have produced the separation of the States and civil war." The money is paid.

While these financial negotiations are underway, General Crook establishes his headquarters on the property of a well-known antislavery Quaker, "Samuel C--.." Crook has threatened to tar and feather Samuel, but the Quaker buys his way out of this punishment. While negotiating the price, Crook asks:

Next, how many negroes have you assisted to escape from their masters; how many have you harbored, hidden, stolen? How many pamphlets have you circulated in the South inciting servile insurrections? How many antislavery newspapers have you supported; ... We have borne much and long without retribution, until, at last, the cup is overflowing! You must acknowledge that the Southern people never interfered with any of your domestic arrangements; they never despoiled you of any of your property; and, above all, they never placed torches and knives in the hands of the debased among you to consume your dwellings and to cut the throats of your wives and children! 
Samuel agrees to pay ten thousand dollars as the price to avoid tar and feathering, but he also admits to being a hypocrite:

But I was a slave-trader, and made my money in Brazil . . . one of the most successful traders between the coast of Africa and the Brazilian empire was a New Jersey Quaker. I am that man.

Crook forces Samuel to drink a toast to the health of "King Cotton," and he tells the Quaker that the money paid as tribute will be "judiciously expended in halters."

Later in the novel this same Quaker is interviewed by General Ruffleton, the Northern despot. Samuel objects to the use of the free colored troops that Ruffleton is organizing and training to employ against the South. The Quakers, Samuel states, have liberated these men so that they might "become members of our society." After some degrading remarks about the inferiority of Negroes, Ruffleton points to the black troops and remarks: "And such are specimens of humanity ... that you would put on an equal footing with the white man!" In hushed tones, Samuel admits that he differs with his fellow Quakers about the equality of races.

Jones is not satisfied to "expose" the abolitionists as hypocrites and fanatics; he portrays a number of them as being viciously cruel. Thus, while Crook is denouncing Quakers in New Jersey, Ruffleton, consolidating his despotic rule in the North, seeks the help of the abolitionists. Ruffleton establishes the "Tribunal of Three" in every large town. This tribunal of judges functions to mete out punishment to political heretics, trouble-makers, and former enemies. Throughout New England, guillotines are set up in public places so that the inhabitants will learn the price of dissent. The novelist admits that the guillotine is more French than American, but Ruffleton, according to Jones, seems impressed by its effectiveness. In Boston, the tribunal is composed of some of the abolitionists who had been sent to Liberia, but who have returned and found Ruffleton's despotic regime friendly. Elsewhere in New England the tribunals often are made up of judges who were unversed in the law. Jones remarks that the judges "were very frequently parsons of the dissenting sects, famous for their abolition propensities, and admirably qualified to try and execute the Catholics and Episcopalians." In Boston, for 
example, a Catholic bishop was condemned to die, his offense being that he had "enjoined upon his clergy the duty of abstaining from participation in discussion on the subject of slavery."

Even the slaves despise the abolitionists. Toward the end of the novel, the President's daughter plans to stay up through the night in order to get some important letters written and asks her Negro maid to bring her cake and wine. Receiving this, she dismisses her maid, telling her to get her rest, for "we labor for you as well as for ourselves, for you are members of our families, and shall share our good as well as our evil fortunes." One of the Negro maids, speaking for the others, says: "Miss Alice ... all de Abolitionists in de world couldn't make us desert you! And brother Pompey, who was wid General Fell [The Southern General who plans to help the North], has stole away, and says none of de dark folks are gwine to fight agin de President.”

What, then, is Jones' attitude toward the North and the abolitionists? Jones uses the device of having the Southern firebrand, General Crook, mouth most of the violent denunciations against the abolitionists, but President Randolph-usually detached and moderate-seems sympathetic to these anti-abolitionist views. Moreover, the abolitionists are depicted consistently as being hypocrites, fanatics, and tyrannical.

Jones' attitude toward abolition and the North seems summed up in a speech given a Southern general: "Equality in the Union, or independence out of it. . . . Nor would I desire to see slavery re-established against the people's will in the States where it has been abolished." For Jones, then, the South wants slavery and it is their constitutional right to maintain this institution if the people in the Southern states so decide. On the other hand, if the North wants to abolish slavery, that is its right. The abolitionists, however, according to Jones, want to force their beliefs upon the South, and in this they violate the rights of the South.

Though the Union is saved in Jones' dream vision, he sees the possibility of a break-up of the Republic, a disunion that might be brought about because the North, urged on by the fanatic abolitionists, might insist upon enforcing its views upon the South. As one leading Southern spokesman says to President Randolph: 
... if either section were to seek to deprive the other of its constitutional rights, so that the people of the opposing sections were unanimous, then separation would be quite a different thing-it would be the same as the separation of the Colonies from Great Britain, which Washington approved, and which his Maker seemed to sanction. 